KOLOM ILMIAH

Social Humaniora

\title{
PERAN MEDIA SOSIAL DAN PARTISIPASI POLITIK REMAJA DALAM KONTEKS KOMUNIKASI POLITIK DI KABUPATEN SUMBAWA
}

\author{
Abyyzar Aggasi \\ Fakultas Ilmu Komunikasi Universitas Teknologi Sumbawa \\ abbyzaraggasi18@gmail.com
}

\begin{abstract}
ABSTRAK
Untuk melihat peran media sosial dan partisipasi politik remaja dalam konteks komunikasi politik di Kabupaten Sumbawa, peneliti menggunakan mixed methodology yaitu memadukan antara metode survey (kuantitaf) dengan metode kualitatif focus group discussion (FGD). Dalam penelitian ini, peneliti melakukan survey pada 50 responden yang terdiri dalam kategori remaja di Kabupaten Sumbawa. Selanjutnya, untuk mendapatkan temuan data yang mendalam, peneliti mengelaborasi hasil temuan survey melalui focus groub discussion (FGD) bersama 5 orang responden yang berpotensi menjadi narasumber yang mantab. Pemilihan responden FGD menggunakan purposive sampling.

Penelitian ini diharapkan mampu memberikan gambaran keterlibatan remaja pada partisipasi politik dalam konteks komunikasi politik dengan adanya media sosial yang hidup dan berkembang di tengahtengah mereka. Selain itu, penelitian ini juga diharapakan dapat memberikan kontribusi bagi perkembangan ilmu komunikasi khususnya dalam konteks komunikasi politik dalam era media baru, terlebih untuk memetakan partisipan politik yang berasal dari kalangan remaja sebagai pengguna aktif media sosial.
\end{abstract}

\section{Pendahuluan}

Partisipasi politik adalah salah satu bentuk upaya keterlibatan aktif masyarakat dalam turut serta menciptakan keputusan politik. Budiharjo (2008) menjelaskan bahwa patisipasi politik dapat diartikan sebagai kegiatan seseorang atau sekelompok orang untuk ikut serta secara aktif dalam kehidupan politik, seperti melaksanakan proses pemilihan pemimpin (memberikan suara dalam pemilu), dan tindakan baik secara langsung maupun tidak langsung melakukan tindakan-tindakan yang dapat mempengaruhi kebijakan politik, seperti menghadiri rapat umum, contracting dan lobbying dengan pejabat pemerintah atau anggota parlemen, menjadi anggota partai atau salah satu anggota gerakan mansyarakat dengan aksinya, dan lain sebagainya.

Partisipasi politik merupakan manifestasi dari kedaulatan rakyat dalam sebuah negara yang demokratis. Rakyat berpartisipasi dalam politik berdasar kepercayaan dan kesadaran politik, bahwa sebagai pemegang kedaulatan, kegiatan partisipatif yang mereka lakukan dapat memiliki dampak politik untuk memenuhi aspirasi yang diinginkan. Dalam negara modern, angka partisipasi politik yang tinggi dianggap sebagai bentuk kematangan kehidupan demokrasi di negara tersebut.
Secara teoritis perlu disadari ada partisipasi yang bersifat otonom dan sukarela, dan ada partisipasi yang bersifat dikerahkan, serta ada pula perdebatan bahwa rendahnya partisipasi politik di negara yang demokrasinya sudah mapan tidak berarti menunjukkan rendahnya kesadaran politik warga negaranya. Dalam hal ini, unsur kunci yang perlu ditekankan untuk mendefinisikan posisi partisipasi politik adalah kesadaran warga negara untuk berperan serta secara aktif baik langsung maupun tidak langsung untuk mempengaruhi keputusan politik dan kebijakan publik, terutama yang berkaitan langsung dengan kepentingan yang bersangkutan.

Begitu pula dalam era digital saat ini, bentuk pertisipasi politik masyarakat tidak lagi terpaku pada metode konvensional yakni face to face dan hand by hand, tetapi lebih kepada bentuk partisipasi yang termediasi media digital. Salah satunya adalah media social yang media ruang publik dalam menuntukan bentuk keterlibatan mereka dalam politik. Hal tersebut juga disari dengan meningkatnya jumlah mengguna media social setiap tahunnya dimana dengan fakta tersebut menunjukan bahwa keterlibatan aktif masyarkat dalam menciptakan indentitas dunia maya juga menaik tajam. Bungin (2006) menyebutkan fenomena tersebut adalah bentuk upaya 
masyarakat dalam dalam mengaplikasikan hyper-realitas dunia nyata kedalam dunia maya.

Sedangkan Quan-Hasse \& Young (2012) dalam risetnya mengidentifikasikan dua tren penting mengapa msyarakat menggunakan media social, pertama, masyarakat tidak merangkul secara utuh media social tersebut, tetapi lebih memadu-padankan bentuk komunikasi offline dan online dalam media social; kedua, masayrakat mengadopsi media social sebagai suatu fenomena gaya hidup untuk menunjukan kemampuan mereka dalam berkomunikasi.

Dalam kurun waktu dua decade terkahir, perkembangan media social menjamur secara cepat. Hadirnya beragam media social dengan beragam keunikan dan segmentasi user (pengguna) yang berbeda-beda mengakibatkan semakin banyak pula ruang virtual (cyber space) bagi masyarakat untuk menyampaiakan aspirasi dan menunjukan keterlibatan politik mereka secara digital. Tidak terkecuali bagi kalangan remaja yang memengang angka jumlah penduduk terbanyak saat ini., dan menjadi sasaran pasar dari media sosia-media social popular seperti Frienster, Facebook, Twitter, Instagram dan lainnya. Menurut situs Facebook Marketing Statistics, Demographics, Reports, and News (www.checkfacebook.com; data diambil 17 Juni 2016: 16.30), total pengguna Facebook di seluruh dunia adalah 867.988.160 (menjadikannya media sosial terbesar di dunia, melampaui Twitter, MySpace, Linkedlin, atau Friendster), dan Indonesia adalah negara pengguna terbesar ke-4 (setelah AS, Brazil dan India) dengan total audien 43.831.900 pengguna. Dari besaran itu, $68,8 \%$ nya (atau setara dengan 30.177.780), adalah pengguna remaja dalam rentang usia 13-24 tahun, dimana secara lebih spesifik 18.260.180 orang adalah pengguna di kelompok usia 18-24 tahun (atau setara 41,6\% dari keseluruhan populasi pengguna facebook di Indonesia).

Serpendapat dengan itu, BPS 2014 menyebutkan bahwa salah satu daerah di wilayah bagian tengah Indonesia, yakni Kabupaten Sumbawa menjadi salah satu daerah dari beberapa daerah lainnya yang memiliki jumlah penduduk dengan remaja sebagai pemegang proporsi dari struktur tersebut.

Oleh karena itu, sebagai pemengang proporsi jumlah penduduk terbesar dalam strutuk, remaja memiliki sudut pandang tersendiri dalam keterlibatan politik mereka di masyarakat. Hal tersebut menggiring penelitian ini untuk melihat isu yang berkaitan dengan masalah remaja antara lain adalah isu pemilih pemula dan isu komunikasi politik yang dilakukan pejabat politik terhadap remaja, khususnya di remaja di Kabupaten Sumbawa.

\section{Kerangka Konsep \\ A. Partisipasi Politik}

Secara umum, partisipasi politik dapat didefinisikan sebagai kegiatan seseorang atau kelompok orang untuk ikut serta secara aktif dalam kehidupan politik, antara lain dengan jalan memilih pemimpin (memberikan suara dalam pemilu), maupun secara langsung atau tidak langsung melakukan tindakan-tindakan yang dapat mempengaruhi kebijakan publik, seperti menghadiri rapat umum, contacting and lobbying dengan pejabat pemerintah atau anggota parlemen, menjadi anggota partai atau salah satu gerakan sosial dengan direct actionnya, dan sebagainya (Budiardjo, 2008).

Upaya untuk melihat pola dan mengukur kekuatan partisipasi politik dapat dilakukan dengan menggunakan piramida partisipasi politik. Kategorisasi partisipasi I dibuat oleh L. Milbrath dan M. Goel, yang membagi masyarakat dalam tiga golongan: pertama, 33\% dari populasi tergolong sebagai apatis, yaitu orang-orang yang tidak aktif sama sekali, termasuk tidak menggunakan hak pilihnya; kedua dalah penonton (spectators) yang dikategorikan aktif secara minimal, termasuk memakai hak pilihnya, yaitu sebesar $60 \%$ dari populasi; dan ketiga adalah $5-7 \%$ populasi yang sangat aktif dalam dunia politik, dan karenanya disebut pemain (gladiators).

Kategorisasi yang lebih lengkap dibuat oleh David F. Roth dan Frank L. Wilson, yang membagi masyarakat menjadi apolitis (apoliticals), penonton (onlookers; yaitu orangorang yang menghadiri acara-acara politik, anggota dalam kelompok-kelompok kepentingan, pelobi, pemilih dalam pemilu, orang-orang yang terlibat dalam diskusi politik, dan pemerhati pembangunan politik), lalu partisipan (participants; yaitu seperti orang yang bekerja untuk kampanye

\section{B. Remaja}

Remaja berasal dari kata latin adolescence yang berarti tumbuh atau tumbuh menjadi dewasa. Istilah adolescence mempunyai arti yang lebih luas lagi yang mencakup kematangan mental, emosional sosial dan fisik (Hurlock, 1992). 
Menurut WHO (badan PBB untuk kesehatan dunia) batasan usia remaja adalah 12 sampai 24 tahun. Sedangkan dari segi program pelayanan, definisi remaja yang digunakan oleh Departemen Kesehatan adalah mereka yang berusia 10 sampai 19 tahun dan belum kawin. Sementara itu, menurut BKKBN (Direktorat Remaja dan Perlindungan Hak Reproduksi), batasan usia remaja adalah 10 sampai 21 tahun. Rentang waktu usia remaja ini biasanya dibedakan atas tiga, yaitu 12-15 tahun = masa remaja awal, 15-18 tahun = masa remaja pertengahan, dan 18-21 tahun = masa remaja akhir.

Berbeda dengan itu, Monks, Knoers, dan Haditono membedakan masa remaja menjadi empat bagian, yaitu masa pra-remaja 10-12 tahun, masa remaja awal 12-15 tahun, masa remaja pertengahan 15-18 tahun, dan masa remaja akhir 18- 21 tahun (Deswita, 2006). Dalam penelitian ini, batas usia remaja yang digunakan adalah kriteria dari BKKBN yaitu usia antara 10 sampai 21 tahun.

\section{Media Sosial}

Media sosial adalah suatu struktur sosial yang dibentuk dari simpul-simpul seperti individu atau organisasi yang diikat dengan satu atau lebih tipe relasi spesifik seperti nilai, visi, ide, teman atau keturunan. media sosial adalah struktur sosial yang terdiri dari elemenelemen individual atau organisasi. Jejaring ini menunjukan jalan dimana mereka berhubungan karena kesamaan sosialitas, mulai dari mereka yang dikenal sehari-hari sampai dengan keluarga. Istilah ini diperkenalkan oleh profesor J.A. Barnes di tahun 1954.Sejak komputer dapat dihubungkan satu dengan lainnya dengan adanya internet banyak upaya awal untuk mendukung media sosial melalui komunikasi antar komputer

(lumansupra.files.wordpress.com/2010/04/ makalah_koran.doc,diakses 17 Mei 2016: 16.30).

Dalam dunia internet, media sosial diwujudkan dalam sebuah layanan online berbasis web yang menjadi sarana bagi penggunanya untuk dapat berinteraksi seperti chat, messaging, email, video, chat suara, share file, blog, diskusi grup, dan lain-lain. Beberapa media sosial memiliki fitur tambahan seperti pembuatan grup untuk dapat saling sharing didalamnya.Media sosial yang dimaksud dalam penelitian ini adalah facebook dan twitter.

\section{Partisipasi Politik Remaja Melalui Media Sosial}

Beberapa hasil penelitian menunjukkan bahwa keterlibatan dan partisipasi politik remaja tidak sekuat generasi orang tua mereka. Namun demikian, dengan kehadiran internet sebagai "lingkungan baru", memunculkan bentuk "new politics" yang berbasis jejaring dunia maya, seperti penggalangan dukungan melalui pembuatan website, kampanye melalui email, dan di kasus pemilihan presiden AS 2004 menunjukkan kasus pemanfaatan media sosial (facebook) sebagai elemen kunci kemenangan Barrack Obama dengan cara yang mudah dan murah. Internet kemudian menjadi lahan permainan politik baru ( $a$ new playground for politics). Penelitian Calenda dan Meijer (2007) di tiga negara (Spanyol, Italia dan Belanda) membangun hipotesis bahwa karena remaja adalah kalangan yang paling banyak mengakses internet, maka partisipasi politiknya kemungkinan diekspresikan melalui internet juga. Namun dari 2163 responden, disimpulkan bahwa internet memang memicu munculnya bentuk partisipasi politik baru, namun tidak mampu menggeser pola lama dalam partisipasi politik (old politics).

Hasil yang kurang lebih sama muncul dalam studi Cohen dan Kahne dkk. (2012) di AS menyebutkan bahwa tidak berarti remaja yang terlibat/melakukan partisipasi politik di new media, akan menganggap sepi partisipasi politik melalui mekanisme kelembagaan resmi (institutional politics). Data hasil survey yang dilakukan menyebutkan bahwa responden yang terlibat di "participatory politics", kemungkinan juga akan terlibat di "institutional politics". "Participatory politics" dianggap hanya sebagai jalur komunikasi untuk mempromosikan kepentingan ketimbang mempengaruhi secara langsung pembuatan keputusan/kebijakan (Data from our survey indicate that youth who engage in participatory politics are much more likely to also engage in institutional political activities such as voting than are those who do not engage in participatory acts. Still, because many forms of participatory politics focus on communication, it may be that they do more to promote voice than influence.

\section{Metode}

Penelitian ini mengguankan mixed method dimana peneliti mengkolaborasikan metode 
survey lapangan kepada 50 responden kemudian data survey tersebut di perdalam menggunakan metode kualitatif Focus Group Discussion (FGD) terhadap 5 orang responden yang berpotensi menjadi narasumber data yang mantab (purposive sampling).

\section{Hasil Penelitian}

\section{A. Remaja dan Media Sosial}

Media sosial merupakan kebutuhan yang cukup penting bagi sebagian masyarakat dunia. Masyarkat kini hidup dengan membawa dua identitas dunia kehidupan. Bungin (2006 : 64) mengungkapkan bahwa kini masyarakat hidup dengan membawa dua identitias dunia kehidupan, yaitu identitias kehidupan masyarakat nyata, dan indentitas kehidupan masyarakat maya.

Fenomena tersebut tidak terkecuali terjadi pada remaja di Indonesia. Angka pengguna remaja media sosial di Indonesia sendiri cukup fantastis, salah satu contohnya ialah pengguna Facebook dari kalangan remaja mencapai 46,1\% dari total populasi pengguna Facebook di Indonesia.

Tabel Kepemilikan Media Sosial Responden

\begin{tabular}{|l|l|l|l|l|}
\hline Kepemilikan Media Sosial & Jumlah & $(\boldsymbol{\%})$ & Laki-Laki & Perempuan \\
\hline Facebook & 50 & 100 & $\mathbf{2 5}$ & $\mathbf{2 5}$ \\
\hline LinkedIN & 23 & 46 & 10 & 13 \\
\hline Twitter & 31 & 62 & 14 & 24 \\
\hline Instagram & 50 & 100 & 25 & 25 \\
\hline Line & 42 & 84 & 18 & 24 \\
\hline Path & 37 & 74 & 14 & 23 \\
\hline Aks.FM & 2 & 4 & 0 & 2 \\
\hline
\end{tabular}

Keseluruhan dari responden memiliki lebih dari satu akun media sosial berbeda. Diantara keseluruhan media sosial yang disebutkan responden, Facebook dan Instagram merupakan media sosial yang dimiliki oleh keseluruhan responden. Fakta bahwa Facebook merupakan media sosial yang memiliki fasilitas yang lebih lengkap dibandingkan media sosial lainnya juga turut mempengaruhi ketertarikan remaja responden penelitian ini. Sependapat dengan itu, Jenkins (dalam Kraps, 2010 : 10) mengungkapkan bahwa Facebook memiliki fasilitas seperti deretan berita, status update, marketplace, group, fanspace, hingga pada hastag berita terkini.

\section{B. Penggunaan Media Sosial Pada Remaja}

Media sosial masih menjadi rumah yang nyaman bagi remaja untuk dapat mengekplorasi dirinya. Melalui berbegai aktifitas yang dapat mereka lakukan di media sosial, remaja mampu terlepas dari kontrol sosial masyarakat yang mengikatnya. Selain itu, remaja juga mampu menyuarakan opini dirinya sesuai dengan perasaan yang mereka rasakan. Responden dalam penelitian ini juga menunjukan hal serupa dimana aktifitas-aktifitas bermedia sosial adalah sarana bagi mereka untuk dapat mengaktualisasikan dirinya di dalam masyarakat dunia maya.
Diantara ragam pilihan aktifitas bermedia sosial, remaja responden di Kabupaten Sumbawa menunjukan intensitas yang tinggi pada kegiatan memperbarui status dalam dinding mereka dan juga mempublikasi fotofoto kegiatan keseharian mereka.

Namun, terdapat beberapa aktifitas yang menajadi dominan dan wajib bagi keseharian bermedia sosial mereka. Dalam pilihan yang diberikan peneliti dalam kuisioner, responden juga memberikan gambaran aktifitas lainnya dalam bermedia sosial seperti melakukan siaran Live melalui Facebook dan Instagram, mengikuiti grub-grub komunitas mereka, mengikuti halaman-halaman popular yang mereka minati.

Aktifitas-aktifitas di media sosial tersebut merupakan tindakan sosial yang secara alamiah remaja tunjukan kepada publik sebagai bukti keterlibatan mereka sebagai bagian dari masyarakat dunia maya. Diantara beragam aktifitas yang dapat dilakukan oleh remaja melalui media sosia, menyuarakan opini melalui kolom komentar adalah presentase tertinggi dari aktifitas remaja di Kabupaten Sumbawa tersebut.

Menyuarakan opini melalui kolom komentar merupakan sebuah gambaran dari timbal balik komunikan terhadap pesan media yang mereka terima. Seiring dengan itu, timbal 
balik pesan media dalam penyebarannya semakin berkembangan dan dapat dilakukan dengan cepat melalui media digital seperti media sosial ini. Dengan adanya fasilitas tersebut, masyarakat khususnya remaja mampu menyuarakan pendapat personalnya terkait masalah-masalah yang menggelitik benaknya.

Dari beragam aktifitas bermedia sosial, memberikan komentar terhadap terbitanterbitan yang muncul di beranda mereka merupakan pilihan yang dominan. Walaupun dalam presentase aktivitas bermedia sosial remaja lebih memilih untuk mengunggah foto dan memperbarui statusnya, namun tidak demikian ketika mereka digiring untuk memilih salah satu aktifitas yang paling mereka minati. Terdapat jumlah $42 \%$ dari keseluruhan respoden yang menyukai aktivitas memberikan komentar ketika bermedia sosial.

Keaktifan remaja dalam beraktifitas melalui media sosial menunjukan intensitas yang massif dalam kesehariaan mereka yang bersinggungan langsung dengan media sosial tersebut. Dari 50 responden penelitian ini, $76 \%$ dari mereka mengakui bahwa mereka mengakses media sosial setiap harinya. Presentase tersebut cukup tinggi dan hampir berimbangan antara remaja dengan jenis kelamin laki-laki yang sebesar $68 \%$ dan remaja dengan jenis kelamin perempuan sebesar $72 \%$. Sisanya, $22 \%$ dari mereka mengakui mengakses media sosial sekitar 2-3 kali dalam satu pekannya, dan $2 \%$ sisanya mengakui mengakses media sosial tidak menentu, atau dapat dikatakan lebih dari batas waktu perhitungan yang telah diberikan.

\section{Topik dan Pembahasan Media Sosial Remaja}

Beragam topik dan pembahan turut menggiring partisipasi remaja menjadi penguna media sosial aktif. Dari ragam topik dan pembahasan, remaja dengan jenis kelamin lakilaki dan perempuan memilik topik acuan yang berbeda masing-masingnya. Seperti yang tertera dalam tabel 3.2 dibawah yang menunjukan bahwa remaja dengan jenis kelamin lak-laki lebih memendang bahwa media sosial sebagai media komunikasi yang digunkankan sebagai ruang diskusi membahas beragam isu-isu hangat terkini dan aktual di sekitar mereka. Dari hal tersebut, terlihat bahwa remaja dengan jenis kelamin lak-laki lebih memandang bahwa media sosial sebagai ruang publik untuk mengeksplorasi pemikiran mereka dan menguji tingkat ketajaman analisis mereka terkait isu-isu tersebut. Selain itu, hasil tersebut juga berbanding tiping dengan presentase topic bahasan masalah personal remaja lak-laki. Remaja laki-laki juga memandang bahwa media sosial sebagai media yang dapat mereka manfaatkan untuk mengekplorasi masalahmasalah personal yang mereka miliki.

Tabel Masalah Yang Menjadi Topik Pembahasan Media Sosial

\begin{tabular}{|l|l|l|l|l|l|l|}
\hline \multirow{2}{*}{ Topik } & \multicolumn{2}{|c|}{ Laki-Laki } & \multicolumn{2}{c|}{ Perempuan } & \multicolumn{2}{c|}{ Total } \\
\cline { 2 - 8 } & Jumlah & \% & Jumlah & \% & Jumlah & \% \\
\hline Masalah Personal & 8 & 32 & 17 & 68 & 25 & 50 \\
\hline Masalah Gaya Hidup & 2 & 8 & 5 & 20 & 7 & 14 \\
\hline Masalah Pendidikan & 0 & 0 & 0 & 0 & 0 & 0 \\
\hline Masalah Isu-Isu Aktual & 9 & 36 & 3 & 12 & 12 & 24 \\
\hline Masalah Bisnis & 3 & 12 & 0 & 0 & 3 & 6 \\
\hline Masalah Pekerjaan & 3 & 12 & 0 & 0 & 3 & 6 \\
\hline
\end{tabular}

Fakta bahwa remaja laki-laki lebih memilih untuk membicarakan isu-isu aktual dan masalah personal menggiring pandangan bahwa remaja laki-laki memanfaatkan media sosial sebagai media diskusi interaktif terkait topik terkini. Selain itu, fakta bahwa masalah pendidikan tidak pernah menjadi topik yang bersinggungan dengan remaja laki-laki di media sosial. Tidak hanya itu, persoalan tersebut juga nampak pada remaja perempuan yang juga lebih menspesifikasikan masalah personal dan gaya hidup sebagai topik dominan dalam pembicaran media sosial.

Remaja perempuan yang lebih mendang bahwa media sosial sebagai media komunikasi penyalur aspirasi personal. Dalam hal ini, remaja perempuan menjunjukan intensitas yang tinggi dalam memanfaatkan media sosial sebagai media komunikasi interpersonal dengan teman, saudara, relasi dan rekanan mereka. 
Pemanfaatan media sosial sebagai media komunikasi interpersonal tersebut biasanya ditunjukan dengan kegiatan mencurahkan isi hati, menjalin hubungan asmara, berhubungan dengan keluarga, dan peningkatan pengetahuan seksualitas mereka. Selain itu, presentase tertinggi berikutnya adalah pembahasan terkait gaya hidup.

Remaja laki-laki dan perempuan secara fisik dan pemikiran memiiliki perbedaan yang cukup signifikan. Sebagai bagian dari masyarakat dunia maya, remaja turut berpartisipasi menjadi anonimitas identitas masyarakat dunia maya dimana mereka merasa lebih nyaman untuk hidup dan berkomunikasi melalui dunia maya. Remaja laki-laki dalam presentase sejumlah 36\% mengakui bahwa mereka merasa lebih mendapat pendengar yang baik dan dukungan ketika mereka berbicara di media sosial. Sedangkan 32\% lainnya merasa bahwa media sosial adalah sebuah sarana untuk mereka dapat leluasa untuk berbicara tanpa adanya ikatan nilai dan budaya yang mengikat mereka. Sisanya, mereka memandang bahwa media sosial adalah satu-satunya saluran dimana tempat mereka untuk berkomunikasi kepada publik. Selain itu, mereka juga memandang bahwa tersedianya konektivitas yang luas di media sosial menjadi dasar yang cukup tegas untuk mereka membicarakan masalah-masalah melalui media sosial.

Remaja perempuan memiliki pandangan yang berbeda. Dalam presentase angka yang cukup tinggi yakni sekitar $60 \%$ didasari oleh rasa leluasa ketika mereka membicarakan masalah melalui media sosial. Lebih dari seperempat (28\%) lainnya juga justru memandang bahwa media sosial adalah saluran dimana mereka bisa mendapatkan dukungan dan didengarkan segala aspirasi yang mereka sampaikan. Sisaanya, memandang bahwa tidak adanya alasan khusus mengapa mereka memilih untuk berbicara tentang masalah melalui media sosial. Mereka hanya merasa nyaman dengan sarana dan fasilitas yang tersedia di media sosial sehingga membuat mereka lebih memilih untuk membicarakan masalah melalui media tersebut.

\section{Keterlibatan Keterlibatan Remaja dalam Politik di Media Sosial}

Hasil dalam penelitian ini juga menunjukan bahwa remaja turut berpartisipasi aktif dalam membicarakan isu-isu politik yang sedang hangat di masyarakat melalui media sosial. Di
Kabupaten Sumbawa, terdapat $76 \%$ remaja yang membahas isu politik di tingkat nasional mereka bermedia sosial, 64\% mereka membicarakan isu politik di tingkat daerah, dan $0 \%$ pada tingkatan sekolah dan universitas. Terdapat jumlah $24 \%$ remaja yang merasa tidak tertarik dengan isu politiik pada tingkatan apapun.

Partisipasi remaja dalam isu politik melalui media sosial dengan angka yang cukup tinggi memperlihatkan bahwa remaja sangat terpengaruh secara dominan pada isu-isu nasional yang cukup viral di media sosial. Dari maraknya pembicaraan isu politik nasional, turut menggiring partisipasi mereka dalam keterlibatan pembahasan isu politik di tingkat daerah seperti PILKADA, tokoh-tokoh pemimpin daerah, kebijakan-kebijakan, dan lain sebagainya.

Namun ketika ditilik lebih mendalam terkait isu pembahasan politik yang mereka perbincangkan melalui media sosial, 38 orang remaja memliki keterlibatan dalam pembicaran isu politik. Setiap remaja yang mengakui menyukai isu politik memiliki pilihan lebih dari satu pilihan terkait isu apa yang gemar mereka bahas. Dari 38 remaja tersebut, 33 anak remaja memliki minat khusus pada isu pemilu seperti pemilihan kepada daerah, presiden, dan pemilihan anggota DPR, 32 remaja menyukai pembahasan terkait figur-figur dan tokoh politik yang mengisi posisi jabtan fungsional dalam strata politik nasional seperti menteri, kepala lembaga organisasi, dan lain sebagainya, 30 remaja juga mengakui menyukai isu permasalah yang terkait dengan perilaku politik seperti permasalahan-permasalahan yang mengeluti mereka, karir positif mereka, dan lain sebagainya.

Terkait dengan isu pemilu baik di tingkat nasional, remaja yang menyakan menyukai isu tersebut mengakui bahwa topic pembicaraan terkait dengannya sering sekali mereka bahas tidak hanya di media sosial. Bahkan di dunia nyatapun mereka juga turut membicarakan isu tersebut baik secara formal dalam forum belajar maupun non formal dalam diskusi santai bersama teman-temannya.

Selain itu, terkait isu politik daerah yang secara tidak langsung bersinggungan dengan mereka, juga turut menjadi sorotan yang menarik bagi remaja. Namun bedanya, euphoria yang terdapat dalam isu politik daerah tidak sepanas isu politik nasional. Hal tersebut dikarenakan media-media yang meliput juga 
kurang dapat mempengaruhi secara signifikan pandangan remaja terhadap isu tersebut.

Selain itu, responden dalam penelitian ini juga termotivasi dengan tanggapan positif yang mereka terima ketika mereka memposting isuisu plitik dalam status dan komentar. Remaja ketika menunjukan partisipasi aktifnyang, mereka mencoba untuk terlihat sebagai individu berintelektual tinggi. Oleh karena itu, menulis status, komentar dan lain sebagainya di media sosial secara tidak langsung menanamkan kemadirian kepada remaja dan keberanian untuk mengungkapkan pendapat serta keprihatinan mereka.

Dahl (1989, dalam Putnam, 2000) mengatakan bahwa langkah-langkah tradisional dalam partisipasi politik biasanya ditunjukan dengan suara, kampanye, dan donasi uang yang dilihat dari landasan demokrasi. Namun, banyak penelitian yang memandang bahwa bentuk partisipasi seperti ini telah menurun khususnya di kalangan anak muda (Zukin, Keeter, Adoline, Jenkins, \& Carpini, 2006). Saat ini, bentuk partisipasi politik dilakukan dengan berbagai cara dimana remaja pandang lebih mudah, praktis, fleksibel, dan lebih personal untuk menanggapi isu-isu sosial politik tersebut. Oleh karena itu, melalui media sosial itulah anak muda atau remaja lebih memilih untuk menuangkan aspirasi politik mereka dikarenakan sifat dari media sosial yang cenderung bersifat semi interpersonal dan semi massa.

Dalam penelitian ini, mengarisbawahi bahwa remaja di Kabupaten Sumbawa sangat menyadari keberadaan media sosial sebagai media partisipasi dalam dunia politik. Isi diskusi dalam media sosial menunjukan kepedulian remaja dan pengetahuan tentang isu-isu lokal, nasional, dan internasional yang berada disekitar mereka. Selain isu sosial yang kemudian dikait-kaitkan dengan kebijakan publik, remaja juga selalu merasa tertarik tentnag bergaam isu masalah figure politik seperti kasus korupsi, perselingkuhan, hingga pada prestasi-prestasi yang diraih tokoh-tokoh tersebut. Keritikan pedas tidak segan-segan mereka lontarkan ketika informasi tersebut mereka terima. Kenyataanya, walaupun suara mereka tidak sampai langsung pada pelaku atau tokoh tersebut, remaja ingin menunjukan bahwa pemahaman mereka cukup mumpuni untuk membedaakan tokoh yang positif dengan rekan jejak yang baik, dan tokoh yang banyak menciptakan masalah dalam pemerintahannya. "kasus korupsi itu selalu menarik. Karena gak ada abisnya orang-orang yang korupsi. Bahkan yang gak disangka-sangka aja bisa korupsi gitu. Kaya Dahlan Iskhan kasus BUMD di Jawa timur itu kalau gak salah. Kan Dahlan terkenal prestasinya baik banget waktu menajabat jadi menteri. Tapi siapa sangka dia terjerat kasus di masa lampaunya."

Pemahaman politik pada tingkatan nasional memang cukup mempengaruhi pandangan remaja dalam mengambil keputusan. Isu-isu nasional selalu mengelitik benak mereka sehingga mereka mencoba untuk turut andil dalam mengutarakan pandangan tersebut. Namun, sayangnya, kepemahaman isu daerah kurang begitu panas bagi remaja sehingga mereka merasa hanya pasif menerima informasi daerah tersebut. Bahkan mereka mengakui bahwa media-medai nasional berpengaruh signifikan terhadap pembentukan opini remaja akan isu-isu politik yang berkembang.

"pekara Ahok dengan penistaan Agama dan kasus dia akan maju jadi DKI satu cukup ramai kemarin. Semua orang berkomentar panjang lebar ngomongin ini itu, positifnyalah, negatifnyalah. Tapi kalau dilihat lagi memang itu salah satu serangan politik sendiri bagi Ahok disaat dia akan maju jadi DKI satu. Sedangkan kalau di NTB sendiri kan masih tenang-tenag aja. Paling juga kontroversi siapa yang bakal baju jadi calon Gubernur nanti ....."

Bagi remaja, media massa sangat berpengaruh untuk memicu pembicaraan dan diskusi terkait isu politik. Mereka mendang bahwa media massa mampu menciptakan suasana yang kondusif untuk memulai diskusi yang berkualitas. Media massa lokal dirasa kurang cerdik memangkas berita-berita yang memicu diskusi hebat. Mereka hanya memandang tokoh-tokoh politik dan permasalahan dari sudut pandang yang cukup positif. Oleh karena itu, ketertarikan terhadap isu-isu daerah dirasa sangat minim dibandingkan dengan isu nasional.

\section{PENUTUP}

\section{A. Kesimpulan}

Dari keterlibatan dan partisipasi politik remaja melalui media sosial memberikan gambaran yang beragam bagaimana remaja 
turut serta secara aktif dalam menciptakan ruang diskusi publik terkait berbagi isu politik yang sedang berkembang. Keberadaan media sosial merupakan sarana alternatif dan kondusif bagi remaja untuk dapat mengekplorasi pemikiran mereka dan dibagikan kepada publik. Media-media sosial populer seperti Facebook dan Instagram turut serta menjadi media edukasi bagi remaja dalam memperoleh informasi politik yang beragam.

Melalui media sosial, remaja seringkali hadir menyuarakan opini mereka dengan sangat mudah. Keterlibatan mereka dalam kegiatan diskusi di media sosial juga menunjukan bahwa remaja tidak lagi dipandang sebagai individu yang pasif menerima informasi. Begitu pula dengan arus informasi politik yang remaja terima melalui media sosial. Melaluinya, remaja dapat dengan mudah mengetahu isu-isu terkini terkait politk yang sedang populer di sekitarnya. Namun, dalam penelitian ini memperlihatkan bahwasanya keterlibatan media massa sangat berperan sangat signifikat dalam penciptaan opini remaja terkait isu politik.

Remaja memandang bahwa media massa dalam menciptakan berita sangat bersifat dominan menggiring mereka untuk terlibat dalam diskusi politik di media sosial. Oleh karena itu, remaja juga menunjukan kepemahaman mereka terhadap isu-isu politik nasional lebih mantab daripada isu-isu politik daerah yang seharusnya lebih mereka kenal. Hal tersebut dikarenakan pengaruh berita-berita panas yang diciptakan oleh media massa nasional kemudia menjadi viral dan populer di media sosial. Sedangkan pada isu politik daerah, remaja memandang bahwa penciptaan isu daerah di media sosial kurang mempersuasi mereka untuk terlibat diskusi aktif didalamnya.

\section{B. Saran}

Dalam penelitian ini, peneliti menggunakan dua tahapan pengumpulan data yaitu kuisiuoner dan FGD. Namun dalam penelitian ini, peneliti masih berada pada tahapan analisis berdasarakan FGD yang dilakukan bersama responden dengan mendapatkan hasil yaitu partisipasi politik remaja melalui media sosial di Kabupaten Sumbawa sangat dipengaruhi oleh arus informasi yang mereka dapatkan dari media massa. Maka, di penelitian berikutnya peneliti merasa perli melengkai data temuan tersebut dengan melakukan analisis konten politik pada akun-akun media sosial populer responden.

\section{Referensi}

Barber, Benjamin. 1984. Strong Democracy: Parcipatory Politics for a New Age. Berkeley : University of California Press.

Bennet, W. Lance. 2008. Civic Life Online: Learning how digital media can engage youth. Boston : MIT Press.

Budiardjo, Miriam. 2008. Dasar-dasar Ilmu Politik, Edisi Revisi. Jakarta: PT Gramedia Pustaka Utama.

Bungin, Burhan. 2006. Sosiologi Komunikasi. Jakarta: Prenada Media Group

Calenda, Davide and Albert Meijer. 2007. Young People, the Internet and Political Participation, Findings of a . Metamorfosis Penggunaan Internet di Indonesia: Dari Politik Advokasi hingga Politik Representasi. CoverAge: Journal of Strategic Communication Vol. 1, No. 2, Hal. 140-156, Maret 2011, Fakultas Ilmu Komunikasi, Universitas Pancasila.

Dahl, R. 1989. Democracy and Its Critic. New Heven, Conn : Yale University Press.

Kraps, Jhon. 2014. Building and Maintaining Legitimacy Online : UNICEF's Use of Facebook. Tesis. Charleston : Eastern Illinois University The Keep.

Mutz, Diana C. 2002. The Consequences of Cross-Cutting Networks for Political Participation. American Journal of Political Science 47 (4), 2002 838855.

Print, Murray and Kathy Edwards (ed.). 2007. Youth and Political Participation. Rotterdam/Taipei: Sense Publishers

Putnam, Robert D. 2000. Bowling Alone. New York : Simon \& Schuster

Putri, Oktarina Maharani Sari. Partisipasi Politik Pemuda dan Saluran Aspirasi. Jakarta : LIPI

Skoric, Marko M. and Grace Kwan. 2011. Do Facebook and Video Games Promote Political Participation Among Youth? Evidence from Singapore. JeDEM 3(1): 70-79, 2011 ISSN 2075-9517

Zukin, C. dkk. 2006. A New Engagement. New York : Oxford Universitas 
JURNAL TAMBORA Vol 2 No 3 Desember 2017 
JURNAL TAMBORA Vol 2 No 3 Desember 2017 